\title{
Bazı yerel sarımsak genotiplerinin farklı diş iriliğinde taze sarımsak performanslarının belirlenmesi
}

\author{
Atnan UĞUR $\mathbb{D}^{1}$, Ömer İNAN ${ }^{\circledR 1}$, Ufuk UÇAN ${ }^{\circledR} 2$ \\ 10rdu Üniversitesi Ziraat Fakültesi Bahçe Bitkileri Bölümü 52200 Altınordu/Ordu \\ ${ }^{2}$ Ordu Üniversitesi Fen Bilimleri Enstitüsü 52200 Altınordu/Ordu
}

Alınıș tarihi: 20 Nisan 2021, Kabul tarihi: 17 Mayıs 2021

Sorumlu yazar: Atnan UĞUR, e-posta: atnanugur@gmail.com

\section{$\ddot{0} \mathbf{z}$}

Amaç: Sarımsak çevresel şartlara uyum yeteneği yüksek bir sebze olması nedeniyle geniş bir ekolojide yetiştirilmektedir. Taze yaprakları ve kurumuş dişleri tüketilmektedir. $\mathrm{Bu}$ çalışmada Taşköprü ilçesinden seçilen dört genotipin farklı diş iriliklerinde taze sarımsak performanslarının belirlenmesi amaçlanmıştır.

Materyal ve Yöntem: Çalışmada genotiplerin dişleri ağırlıklarına göre küçük, orta ve büyük olmak üzere üç gruba ayrılmıştır. Sarımsak dişleri 3:1 oranında torf/perlit karışımı ile doldurulmuş 50*16*14 cm ebatlarındaki balkon tipi saksılara dikilmişlerdir. Dikim 1 Kasım tarihinde yapılmış, bakım ve kültürel işlemler sonrası gelişen bitkiler dikim sonrası 75 . günde hasat edilmiştir. Hasat edilen bitkilerde bitki verimi $\left(\mathrm{g} / \mathrm{m}^{2}\right)$, bitki boyu $(\mathrm{cm})$, aks boyu $(\mathrm{cm})$, yeşil aksam boyu (cm), SPAD, yaprak kuru ağırlığı (\%), kök uzunluğu $(\mathrm{cm})$ ve yaprak sayısı (adet/bitki) belirlenmiştir.

Araştırma Bulguları: Genotipler ve diş büyüklügü verim ve kalite özellikleri üzerine etkili bulunmuştur. Bitki verimi değerleri 881.33-2370.33 $\mathrm{g} / \mathrm{m}^{2}$ arasında değişmiştir. Verim özelliklerinde Yazıköy genotipi, SPAD değeri bakımından Yazıköy ve Ömerce genotipleri öne çıkmıştır. Diş büyüklükleri bitki verimde \%103'e varan oranlarda etkili bulunmuştur.

Sonuç: Verim açısından Yazıköy genotipi tercih edilebilir. Duyusal analizlerin yapıldı̆̆ı, bitki sıklığı ve gübrelemenin test edildiği çalıșmaların yapılması önemlidir.

Anahtar kelimeler: Allium sativum L., bitki boyu, kök uzunluğu, SPAD, verim
Determination of fresh garlic performance in different clove sizes of some local garlic genotypes

\section{Abstract}

Objective: Since garlic is a vegetable with high adaptability to environmental conditions, it is grown in a wide ecology. Fresh leaves and dried cloves are consumed. In this study, it was aimed to determine the performance of fresh garlic in different cloves sizes of four genotypes selected from Taşköprü district.

Materials and Methods: In the study, the cloves of the genotypes were divided into three groups as small, medium and large according to their weight. Garlic cloves were planted in $50^{*} 16^{*} 14 \mathrm{~cm}$ sizes balcony type pots filled with a mixture of peat / perlite at a ratio of $3: 1$. Planting was made on November 1 , and the plants that developed after maintenance and cultural processes were harvested on the $75^{\text {th }}$ day after planting. Plant yield (g.m-2), plant height $(\mathrm{cm})$, axle length $(\mathrm{cm})$, green leaves height $(\mathrm{cm})$, SPAD, leaf dry weight $(\%)$, root length (cm) and leaf number (pieces/plant) in harvested plants has been determined.

Results: Genotypes and cloves size were found to be effective on yield and quality characteristics. Plant yield values varied between 881.33-2370.33 g/ $/ \mathrm{m}^{2}$. Yazıköy genotype in yield characteristics, Yazıköy and Ömerce genotypes in terms of SPAD came to the fore. Cloves sizes have been found effective in plant yield up to $103 \%$.

Conclusion: Yazıköy genotype can be preferred in terms of yield. It is important to conduct studies in 
which sensory analyzes are made, plant density and fertilization are tested.

Key words: Allium sativum L., plant height, chlorophyll, root length, SPAD, yield

\section{Giriş}

FAO verilerine göre dünyada 2019 yılında 59.7 milyon ha alanda 1.13 milyar ton sebze üretilmiş olup, bunun \%2.7'sini sarımsak oluşturmuştur. Çin sarımsakta hem üretim miktarı hem de ihracat değerleri açısından dünyada ilk sırada yer almaktadır. Ülkemizde 2019 yılı verilerine göre 103 bin ton kuru, 23.3 bin ton taze sarımsak üretilmiştir. Son yıllarda üretim miktarında bir artış görülmekle birlikte üretim miktarımız iç talebi karşılamadığı için Çin, Suriye, İran ve Mısır'dan 11 bin ton civarında sarımsak ithalatımız söz konusudur (Anonim, 2021). Türk mutfağının vazgeçilmez sebzelerinden olan sarımsak kendine has kokusu nedeniyle sosyal yaşamda tüketiminde çekinceler olabilmektedir. Çinliler, Mısırlılar, Babiller ve Romalıların sarımsağı tedavi edici özellikleri nedeniyle kullanıldıklarına dair bazı kayıtlar ve kanıtlar olduğu bilinmektedir (Dehkordi ve ark., 2010). Hem in vivo hem de in vitro çalışmalar sarımsağın güçlü farmokolojik özelliklere sahip olduğunu ortaya koymuştur (Arzanlou ve Bohlooli, 2010; Batcioglu ve ark., 2012). Özellikle yapısında bulunan kükürtlü bileşiklerin önemli sağlık etkileri olduğu ifade edilmektedir. Sarımsağın biyoaktif bileşenleri esas olarak iyileştirici özellikleri ile bilinmektedir (Santhosha ve ark., 2013). Sarımsağın fizyolojik etkileri, keskin aroma veren tiyosülfatlar gibi uçucu kükürt bileşiklerinin varlığından kaynaklanmaktadır (Agarwal, 1996). Bu bileşikler sarımsaktan izole edilerek ticari preparat olarak satılmaktadır. Toz halindeki hazır preparat kükürtlü bileşikler çiğ sarımsaktakilere göre daha kolay sindirilmektedir (Torres-Palazzolo ve ark., 2021). Dang virüsünün sebep olduğu iltihapların önlenmesi ve oksidatif stresi azaltma konularında da sarımsağın yapısında bulunan organosülfür bileșiklerinin etkili olduğu belirtilmiștir (Hall ve ark., 2017). Sarımsağın kalp damar hastalıkları ve kanser önleyici, kolesterol ve yüksek kan basıncı düşürücü, bağışılklık sistemi güçlendirici, kan sulandırıcı, antibiyotik, antiviral, antifungal ve antiparaziter etkileri konusunda bilgiler mevcuttur (Ayaz ve Alpsoy, 2007). Alisin sarımsağın biyoaktif etkilerinden sorumlu temel bileşendir. Bitkinin doğal yapısında bulunmayıp, ezilme sonrası enzimatik reaksiyon sonucu oluşur
(Tapiero ve ark., 2004). Alisin'in, atletlerde egzesize bağlı kas hasarlarını azaltma, antitrombotik, antikanser ve antioksidant etkileri bilinmektedir. $\mathrm{Bu}$ etkileri nedeniyle günümüzde sarımsak besin takviyesi olarak önerilmektedir (Kik ve ark., 2001; Raman ve ark., 2008).

Sarımsak daha çok kuru sarımsak şeklinde tüketilmekle birlikte taze sarımsak yapraklarının yurtdışında günlük diyetlerde pişirilerek ya da taze olarak salata ve yemeklerde kullanımı nedeniyle taze tüketimleri de artmaya bașlamıștır (Akan ve ark., 2019). Kuru sarımsak üretimi daha çok Kastamonu iliyle özdeşleşmekle birlikte son yıllarda Gaziantep öne çıkmaya başlamıştır (Anonim, 2021). Kaliteli kuru sarımsak yetiştiriciliği için deniz ikliminden kara iklimine geçiş bölgeleri tercih edilmektedir (Vural ve ark., 2000). Taze sarımsak üretiminde vegetasyon süresinin kısa olması ve yumrunun kuruması için kuru ve sıcak bir ekolojiye ihtiyaç olmaması nedeniyle özel bir iklim isteği yoktur. Taze sarımsak nemli ve llk bir iklimde kolaylıkla yetişebilmektedir. İri dişli pembe kabuklu ve az acılı İspanyol sarımsağı ile iri dişli gri kabuklu kara sarımsak çeșitleri taze üretim için tercih edilmektedir (Kütevin ve Türkeş, 1987). Kaliteli bir üretim için yeknesak diş büyüklüğü ve slk yetiştiricilik yapılması gerekmektedir (Vural ve ark., 2000). Ülkemizde taze sarımsağın üretimi konusunda bilimsel çalışma sınırlıdır. Yerel genotiplerin ve diş büyüklügünün taze sarımsakta verim ve kaliteye etkisi önemli bir husus olarak dikkat çekmektedir. Bu çalışmada Taşköprü ilçesinin farklı köylerinden temin edilen sarımsak genotiplerinin farklı diş büyüklüklerinde taze sarımsak performanslarının belirlenmesi amaçlanmıştır.

\section{Materyal ve Yöntem}

\section{Materyal}

Çalışmada Kastamonu ili, Taşköprü ilçesine bağlı Karnıaçık, Ömerce, Yazıköy ve Yeniköy köylerindeki üretici bahçelerinden temin edilen dört adet sarımsak genotipi kullanılmıştır. Genotiplerin ortalama diş ağırlıkları sırasıyla 2.04, 1.83, 2.08 ve 1.92 g'dır. Genotipler temin edildikleri köylerin isimleri ile kodlanmışlardır.

\section{Yöntem}

Çalışmada öncelikle genotiplerin dişleri elle dikkatli bir şekilde ayrılmıştır. Her diş hassas terazi ile tartılmıştır. Dişler büyüklüğüne göre küçük (1.0-1.5 g), orta (1.6-3.0 g) ve büyük ( $>3.0 \mathrm{~g})$ olmak üzere 3 
gruba ayrılmıștır. Isıtmasız plastik serada yürütülen çalışmada, taze sarımsaklar içlerine 3:1 oranında torf/perlit karışımı doldurulmuş $50 * 16 * 14 \mathrm{~cm}$ ebatlarındaki balkon tipi saksılarda yetiștirilmişlerdir. Her saksıya 24'er adet diș sarımsak 1 Kasım tarihinde dikilmiştir. Dikimde dişlerin 2/3'luk kısmının yetiştirme ortamı içerisinde olması sağlanmıştır. Gübreleme olarak 9 $\mathrm{kg} / \mathrm{da}$ azot gübrelemesi eşit miktarlarda dikim sonrası (0. Gün), 15. ve 45. günlerde üç seferde, 6 $\mathrm{kg} /$ da fosfor gübrelemesi dikim sonrası ve 15 . günde eşit miktarlarda iki seferde, potasyum gübrelemesi ise $6 \mathrm{~kg} / \mathrm{da}$ olarak dikimden sonra 15 . ve 45 günlerde iki seferde eșit miktarlarda uygulanmıștır. Çalışma boyunca tüm sulama, ot temizliği gibi kültürel işlemler zamanında ve eksiksiz yerine getirilmiştir (Vural ve ark., 2000). Taze sarımsaklar dikim sonrası 75 . günde hasat edilmişlerdir.
Çalışmada bitki verimi $\left(\mathrm{g} / \mathrm{m}^{2}\right)$, bitki boyu $(\mathrm{cm})$, aks boyu $(\mathrm{cm})$, yeşil aksam boyu $(\mathrm{cm})$, SPAD, yaprak kuru ağırlığı (\%), kök uzunluğu (cm) ve yaprak sayısı (adet/bitki) gibi parametreler belirlenmiştir. Çalışma tesadüf parselleri deneme deseninde 3 tekerrürlü olarak kurulmuş ve her saksı bir parsel olarak alınmıştır. Çalışma sonuçları JUMP 10 istatistik programında analiz edilmiştir.

\section{Bulgular ve Tartışma}

Taşköprü ilçesinde yetiştirilen dört farklı sarımsak genotipinin taze sarımsak performanslarına ait çalışmanın verileri bu bölümde incelenmiştir.

\section{Bitki Boyu, Yeşil Aksam Boyu ve Aks Boyu}

Yerel sarımsak genotiplerinin diş büyüklüğüne bağlı bitki boyu, yeșil aksam boyu ve aks boyuna ait değerler Çizelge 1'de verilmiştir.

Çizelge 1. Sarımsak genotiplerinin diş büyüklüğüne bağlı bitki boyu, yeşil aksam boyu ve aks boyu değerleri (cm)

\begin{tabular}{|c|c|c|c|c|}
\hline Genotip & Diş Büyüklüğü & Aks boyu $(\mathrm{cm})$ & Yeşil aksam boyu (cm) & Bitki boyu $(\mathrm{cm})$ \\
\hline \multirow{4}{*}{ Karnıaçık } & Küçük & 5.66 & 23.33 & 28.99 \\
\hline & Orta & 5.66 & 27.33 & 32.99 \\
\hline & Büyük & 5.66 & 28.33 & 33.99 \\
\hline & Ortalama & $5.66 \mathrm{~B}$ & $26.33 \mathrm{~B}$ & $31.99 \mathrm{~B}$ \\
\hline \multirow{4}{*}{ Ömerce } & Küçük & 5.00 & 24.00 & 29.00 \\
\hline & Orta & 5.66 & 27.66 & 33.00 \\
\hline & Büyük & 5.66 & 29.00 & 34.67 \\
\hline & Ortalama & $5.44 \mathrm{~B}$ & $26.89 \mathrm{AB}$ & $32.22 \mathrm{~B}$ \\
\hline \multirow{4}{*}{ Yazıköy } & Küçük & 6.33 & 25.00 & 31.33 \\
\hline & Orta & 7.00 & 30.00 & 35.66 \\
\hline & Büyük & 7.66 & 29.33 & 37.00 \\
\hline & Ortalama & $7.00 \mathrm{~A}$ & $28.11 \mathrm{~A}$ & $34.66 \mathrm{~A}$ \\
\hline \multirow{4}{*}{ Yeniköy } & Küçük & 5.00 & 21.00 & 26.00 \\
\hline & Orta & 5.33 & 25.00 & 30.33 \\
\hline & Büyük & 5.66 & 27.00 & 32.66 \\
\hline & Ortalama & $5.33 \mathrm{~B}$ & $24.33 \mathrm{C}$ & $29.66 \mathrm{C}$ \\
\hline \multirow{3}{*}{ Ortalama } & Küçük & $5.50 \mathrm{~b}$ & $23.33 b$ & $28.83 c$ \\
\hline & Orta & $5.91 a b$ & $27.50 a$ & $33.00 \mathrm{~b}$ \\
\hline & Büyük & $6.16 a$ & $28.42 a$ & $34.58 a$ \\
\hline \multirow{3}{*}{\multicolumn{2}{|c|}{$\begin{array}{l}\text { öd: önemli değil; * }: \mathrm{P}<0.05 \\
\text { **: }^{\mathrm{P}<0.01 ;}{ }^{* * *}: \mathrm{P}<0.001\end{array}$}} & $\mathrm{LSD}_{\text {genotip }}: 0.74^{* * *}$ & LSD $_{\text {genotip }}: 1.25^{* * *}$ & LSD genotip:1.43*** \\
\hline & & 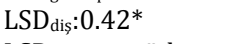 & $\mathrm{LSD}_{\text {diş }}: 1.08^{* * *}$ & $\mathrm{LSD}_{\text {diş }}: 1.24^{* * *}$ \\
\hline & & LSD genotipxdiș:Öd. & LSD genotipxdiș:öd. & LSD genotipxdiş:öd. \\
\hline
\end{tabular}

Çizelge 1'de verilen Yerel sarımsak genotiplerinin diş büyüklüğüne göre bitkilerin aks boyları arasında istatistiki olarak fark belirlenmiştir $(\mathrm{P}<0.05)$. Yazıköy genotipi $7.00 \mathrm{~cm}$ aks boyu ile en uzun aks boyunu vermiş, diğer genotiplerin aks boyları 5.33$5.66 \mathrm{~cm}$ arasında değişmiştir. Diş büyüklüğü aks boyu üzerinde etkili bulunmuş, Büyük dişler $6.16 \mathrm{~cm}$ ile en büyük aks uzunluğuna sahip olmuşlardır. Diş büyüklüğünün artışına paralel olarak aks uzunluğu artmıştır. Yeşil aksam boyu değerleri açısından genotipler ve diş büyüklükleri istatiksel anlamda değişime neden olmuştur. Yazıköy genotipi $28.11 \mathrm{~cm}$ yeşil aksam boyu ile ilk sırada yer almıştır. Ömerce ve Karnıaçık genotipleri Yazıköy genotipini takip etmiş, Yeniköy en kısa yeşil aksam boyulu genotip olmuştur. En küçük diş büyüklüğünde yeşil aksam boyu belirgin derecede azalmıștır. Diğer dişlerin yeşil aksam boyları benzer bulunmuştur. Aks boyu ile yeşim aksam boyunun toplamından meydana gelen bitki boyu değerleri üzerine genotipler ve diş büyüklüklerine göre belirlenen fark istatistiksel anlamda önemli bulunmuştur. Yazıköy genotipi aks boyu ve yeşil aksam boyunda olduğu gibi bitki boyunda da en yüksek değeri vermiștir. Yeniköy 
genotipi $29.66 \mathrm{~cm}$ ile en düşük bitki boyuna sahip olmuş, Karnıaçık ve Ömerce genotipleri benzer bitki boyu değerlerine sahip olmuşlardır. Bitki boyunun diş büyüklügüne göre değişimi belirgin bulunmuş, diş büyüklükleri büyük>orta>küçük şeklinde bitki boyunu etkilemişlerdir. Güral (2014)'ın taze soğanda nispeten iri arpacıktan gelişen genotiplerin daha uzun bitki boylu olmaları ve Zambi (2015)'nin taze soğan üretiminde arpacık iriliğinin artması ile bitki boyu, aks boyu ve yeşil aksam boyunun artması şeklindeki bulguları bizim sonuçlarımızı destekler niteliktedir. İri dişlerde depo besin maddesi durumu ve yeni köklerin oluştuğu aktif bölgenin küçük dişlere göre daha fazla olması nedeniyle erken dönemde beslenme ve kök gelişimi açısından iri dișlere bir avantaj sağlamaktadır. Peker (2019), Diyarbakır koşullarında 10 Kasım, 19 Kasım, 2 Aralık ve 10 Aralık tarihlerinde dikim yaptığı Tunceli, Çermik ve Taşköprü sarımsaklarında bitki boyunun genotiplere göre değiștiğini, ortalama değerler üzerinden en yüksek $57.10 \mathrm{~cm}$ ile Taşköprü genotipinde olduğunu bildirmiştir. Araştırıcı ilkbahar dikimlerinde Taşköprü genotipinde bitki boyunu $51.65 \mathrm{~cm}$ olarak belirlemiştir. Geboloğlu ve ark. (2017) Tokat sarımsağı genotipleri üzerinde yaptığı çalışmada, bitki boyunun 64.00-76.33 cm arasında değiştiğini, şahit olarak alınan Taşköprü genotipinde ise $68.75 \mathrm{~cm}$ olduğunu tespit etmiştir. İki araştırma sonucunda belirlenen değerler bizim bitki boyu değerlerimizden bir hayli fazladır. Geboloğlu ve ark. (2017) Tokat sarımsak genotiplerinde yaprak boyunun 39.17-50.40 cm arasında, Taşköprü genotipinde ise $44.17 \mathrm{~cm}$ olduğunu belirlemiştir. Bakır (1996) sarımsakta dikim zamanlarının etkilerini incelediği çalışmada bitki boylarının 27.36-63.73 cm aralığında olduğunu tespit etmiştir. Bitki boyu, aks boyu ve yeşil aksam boyu değerlerindeki değișime genotip ve ekolojik farklılığı ile bitki beslenme durumları gibi faktörler etki etmektedir. Diğer yandan bizim çalışmamızda yaprak kalitesinde bozulmalar başlamadan önce vegetatif büyüme devam ederken bitkileri hasat yapmamız nedeniyle değerlerimiz düşük bulunmuş olabilir.

\section{Yaprak Sayısı}

Yerel sarımsak genotiplerinin diş büyüklüğüne bağlı yaprak sayısı değerleri Çizelge 2'de verilmiştir.

Sarımsak genotiplerinin yaprak sayısı değerleri üzerine diş büyüklügünün etkisi istatistiksel olarak önemli bulunmuştur. Büyük ve orta dişler küçük dişlere göre taze sarımsakta yaprak sayısını yüzde
12.46-18.26 oranlarında artırmıştır. Gaiki ve ark. (2006) bakteri ve azaltılmış inorganik gübre uygulamalarını araştırdığı çalışmada sarımsakta yaprak sayılarının 8.46-11.26 adet/bitki arasında değiştiğini belirtmiştir. Geboloğlu ve ark. (2017) Taşköprü sarımsağında yaprak sayısını 12.50 adet/bitki olduğunu, Tokat sarımsak genotiplerinde ise 10.33-13.00 aralığında değiştiğini bildirmiştir. Muhtemelen erken dönemde hasat yaptığımız için yaprak sayısı değerlerimiz düşük çıkmıştır. Genotiplerin yaprak sayısı değerleri benzer bulunmuş ve 3.73-3.89 adet/bitki arasında değişmiștir.

Çizelge 2. Sarımsak genotiplerinin diș büyüklüğüne bağlı yaprak sayısı değerleri (adet/bitki)

\begin{tabular}{|c|c|c|}
\hline Genotip & $\begin{array}{l}\text { Diş } \\
\text { Büyüklüğüu }\end{array}$ & $\begin{array}{c}\text { Yaprak Sayısı } \\
\text { (adet/bitki) }\end{array}$ \\
\hline \multirow{4}{*}{ Karnıaçık } & Küçük & 3.40 \\
\hline & Orta & 3.93 \\
\hline & Büyük & 4.20 \\
\hline & Ortalama & 3.84 \\
\hline \multirow{4}{*}{ Ömerce } & Küçük & 3.40 \\
\hline & Orta & 3.73 \\
\hline & Büyük & 4.06 \\
\hline & Ortalama & 3.73 \\
\hline \multirow{4}{*}{ Yazıköy } & Küçük & 3.60 \\
\hline & Orta & 4.06 \\
\hline & Büyük & 4.00 \\
\hline & Ortalama & 3.89 \\
\hline \multirow{4}{*}{ Yeniköy } & Küçük & 3.40 \\
\hline & Orta & 3.80 \\
\hline & Büyük & 4.06 \\
\hline & Ortalama & 3.75 \\
\hline \multirow{3}{*}{ Ortalama } & Küçük & $3.45 \mathrm{~b}$ \\
\hline & Orta & $3.88 a$ \\
\hline & Büyük & $4.08 a$ \\
\hline \multirow{3}{*}{\multicolumn{2}{|c|}{$\begin{array}{l}\text { öd: önemli değil; * : } \mathrm{P}<0.05 \\
\text { **: } \mathrm{P}<0.01 ; * * *: \mathrm{P}<0.001\end{array}$}} & LSD ${ }_{\text {genotip:öd. }}$ \\
\hline & & $\mathrm{LSD}_{\text {diş }}: 0.24^{*}$ \\
\hline & & LSD genotipxdiş:öd. \\
\hline
\end{tabular}

\section{Kök Uzunluğu}

Yerel sarımsak genotiplerinin diş büyüklügüne bağlı kök uzunluğu değerleri Çizelge 3'de verilmiştir.

Kök uzunluğu değerleri üzerine genotip ve diş büyüklüğü istatistiksel anlamda önemli farklılıklar meydana getirmiştir. Ömerce ve Yazıköy genotipleri en uzun köklere sahip olmuş, Yeniköy genotipinin ise en kısa kök uzunluğuna sahip olduğu belirlenmiştir. Diş büyüklüğü arttıkça kök uzunluğu artmıştır. Büyük dişlerden gelişen bitkilerde $32.75 \mathrm{~cm}$ olan kök uzunluğu küçük dişlerden gelișen bitkilerde 28.00 cm olarak belirlenmiştir. Güral (2014)'ın soğan genotiplerinde iri arpacıklardan yetiştirilen bitkilerin daha uzun kök oluşturması şeklindeki bulgusu sonuçlarımızla uyum içerisindedir. 
Çizelge 3. Sarımsak genotiplerinin diş büyüklügüne bağlı kök uzunluğu değerleri $(\mathrm{cm})$

\begin{tabular}{|c|c|c|}
\hline Genotip & Diş Büyüklüğü & Kök Uzunluğu $(\mathrm{cm})$ \\
\hline \multirow{4}{*}{ Karnıaçık } & Küçük & 29.66 \\
\hline & Orta & 30.00 \\
\hline & Büyük & 31.33 \\
\hline & Ortalama & $30.33 \mathrm{~B}$ \\
\hline \multirow{4}{*}{ Ömerce } & Küçük & 29.00 \\
\hline & Orta & 33.00 \\
\hline & Büyük & 35.00 \\
\hline & Ortalama & $32.33 \mathrm{~A}$ \\
\hline \multirow{4}{*}{ Yazıköy } & Küçük & 30.00 \\
\hline & Orta & 33.66 \\
\hline & Büyük & 33.66 \\
\hline & Ortalama & $32.44 \mathrm{~A}$ \\
\hline \multirow{4}{*}{ Yeniköy } & Küçük & 23.33 \\
\hline & Orta & 29.30 \\
\hline & Büyük & 31.00 \\
\hline & Ortalama & $27.88 \mathrm{C}$ \\
\hline \multirow{3}{*}{ Ortalama } & Küçük & $28.00 \mathrm{C}$ \\
\hline & Orta & $31.49 b$ \\
\hline & Büyük & $32.75 a$ \\
\hline \multirow{3}{*}{\multicolumn{2}{|c|}{$\begin{array}{l}\text { öd: önemli değil; }{ }^{*}: \mathrm{P}<0.05 ; \\
{ }^{* *}: \mathrm{P}<0.01 ;{ }^{* * *}: \mathrm{P}<0.001\end{array}$}} & LSD $_{\text {genotip: }} 1.32 * * *$ \\
\hline & & $\mathrm{LSD}_{\text {diș }}: 1.20^{* * *}$ \\
\hline & & LSD genotipxdiș:öd. \\
\hline
\end{tabular}

\section{Yaprak Kuru Ağırlığı}

Yerel sarımsak genotiplerinin diş büyüklüğüne bağlı yaprak kuru ağırlığı değerleri Çizelge 4'de verilmiştir.

Çizelge 4. Sarımsak genotiplerinin diș büyüklüğüne bağlı yaprak kuru ağırlığı değerleri (\%)

\begin{tabular}{|c|c|c|}
\hline Genotip & Diş Büyüklüğü & $\begin{array}{c}\text { Yaprak kuru ağırlığı } \\
(\%)\end{array}$ \\
\hline \multirow{4}{*}{ Karnıaçık } & Küçük & 26.50 \\
\hline & Orta & 30.79 \\
\hline & Büyük & 33.51 \\
\hline & Ortalama & $30.27 \mathrm{~A}$ \\
\hline \multirow{4}{*}{ Ömerce } & Küçük & 25.37 \\
\hline & Orta & 29.24 \\
\hline & Büyük & 31.18 \\
\hline & Ortalama & $28.60 \mathrm{~B}$ \\
\hline \multirow{4}{*}{ Yazıköy } & Küçük & 27.26 \\
\hline & Orta & 30.85 \\
\hline & Büyük & 32.69 \\
\hline & Ortalama & $30.27 \mathrm{~A}$ \\
\hline \multirow{4}{*}{ Yeniköy } & Küçük & 28.59 \\
\hline & Orta & 31.19 \\
\hline & Büyük & 31.92 \\
\hline & Ortalama & $30.57 \mathrm{~A}$ \\
\hline \multirow{3}{*}{ Ortalama } & Küçük & $26.93 c$ \\
\hline & Orta & $30.52 b$ \\
\hline & Büyük & $32.33 a$ \\
\hline \multirow{3}{*}{\multicolumn{2}{|c|}{$\begin{array}{l}\text { öd: önemli değil; * : } \mathrm{P}<0.05 \\
{ }^{* *}: \mathrm{P}<0.01 ;{ }^{* * *}: \mathrm{P}<0.001\end{array}$}} & $\operatorname{LSD}_{\text {genotip }}: 1.21^{* * *}$ \\
\hline & & $\mathrm{LSD}_{\text {diş }}: 1.05^{* * *}$ \\
\hline & & 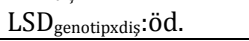 \\
\hline
\end{tabular}

Farklı diş büyüklüğüne göre yetiștirilen sarımsak genotiplerinde yaprak kuru ağırlı değerlerinde istatistiki olarak önemli değişimler belirlenmiştir. Karnıaçık, Yazıköy ve Yeniköy genotipleri gövde kuru ağırlık olarak Ömerce genotipinden yüksek bulunmuştur. Akan (2019) Taşköprü sarımsağında kuru madde oranın \%38.84 olduğunu belirtmiştir. Gadel-Hak ve ark. (2011) sarımsak genotiplerinde kuru ağırlık değerlerinin \%28.31 ile \%35.31 arasında olduğunu bildirmiştir. Bu değerler bizim sonuçlarımızı kısmen desteklemektedir.

\section{Yaprak SPAD Değerleri}

Yerel sarımsak genotiplerinin diş büyüklüğüne bağlı yaprak SPAD değerleri Çizelge 5'te verilmiştir.

Çizelge 5. Sarımsak genotiplerinin diş büyüklüğüne bağlı yaprak SPAD değerleri

\begin{tabular}{|c|c|c|}
\hline Genotip & Diş Büyüklüğü & $\begin{array}{c}\text { Yaprak SPAD } \\
\text { değerleri }\end{array}$ \\
\hline \multirow{4}{*}{ Karnıaçık } & Küçük & $17.33 \mathrm{fg}$ \\
\hline & Orta & 19.33 ef \\
\hline & Büyük & $24.00 \mathrm{bc}$ \\
\hline & Ortalama & $20.22 \mathrm{~B}$ \\
\hline \multirow{4}{*}{ Ömerce } & Küçük & $16.66 \mathrm{~g}$ \\
\hline & Orta & $23.00 \mathrm{~cd}$ \\
\hline & Büyük & $28.00 \mathrm{a}$ \\
\hline & Ortalama & $22.55 \mathrm{~A}$ \\
\hline \multirow{4}{*}{ Yazıköy } & Küçük & 19.33 ef \\
\hline & Orta & $20.67 \mathrm{de}$ \\
\hline & Büyük & $26.00 \mathrm{ab}$ \\
\hline & Ortalama & $22.00 \mathrm{~A}$ \\
\hline \multirow{4}{*}{ Yeniköy } & Küçük & $16.66 \mathrm{~g}$ \\
\hline & Orta & 19.66 ef \\
\hline & Büyük & $17.33 \mathrm{fg}$ \\
\hline & Ortalama & $17.88 \mathrm{C}$ \\
\hline \multirow{3}{*}{ Ortalama } & Küçük & $17.50 \mathrm{c}$ \\
\hline & Orta & $20.67 b$ \\
\hline & Büyük & $26.00 a$ \\
\hline \multirow{3}{*}{\multicolumn{2}{|c|}{$\begin{array}{l}\text { öd: önemli değil; } *: \mathrm{P}<0.05 \\
*^{* *}: \mathrm{P}<0.01 ; * * * \mathrm{P}<0.001\end{array}$}} & LSD $_{\text {genotip }}: 1.49^{* * *}$ \\
\hline & & $\operatorname{LSD}_{\text {diş}}: 1.29 * * *$ \\
\hline & & LSD $_{\text {genotipxdiş }}: 2.59^{*}$ \\
\hline
\end{tabular}

Çizelge 6. Sarımsak genotiplerinin diş büyüklüğüne bağlı bitki verimi değerleri $\left(\mathrm{g} / \mathrm{m}^{2}\right)$

\begin{tabular}{|c|c|c|}
\hline Genotip & $\begin{array}{l}\text { Diș } \\
\text { Büyüklüğü }\end{array}$ & $\begin{array}{l}\text { Bitki verimi değerleri } \\
\left(\mathrm{g} / \mathrm{m}^{2}\right)\end{array}$ \\
\hline \multirow{4}{*}{ Karnıaçık } & Küçük & $1127.67 \mathrm{e}$ \\
\hline & Orta & $1582.33 \mathrm{c}$ \\
\hline & Büyük & $2322.67 \mathrm{a}$ \\
\hline & Ortalama & $1677.56 \mathrm{AB}$ \\
\hline \multirow{4}{*}{ Ömerce } & Küçük & $1077.33 \mathrm{e}$ \\
\hline & Orta & $1493.33 \mathrm{c}$ \\
\hline & Büyük & $2370.33 \mathrm{a}$ \\
\hline & Ortalama & $1647.00 \mathrm{~B}$ \\
\hline \multirow{4}{*}{ Yazıköy } & Küçük & $1228.33 \mathrm{de}$ \\
\hline & Orta & $1722.33 \mathrm{bc}$ \\
\hline & Büyük & $2265.00 \mathrm{a}$ \\
\hline & Ortalama & $1738.55 \mathrm{~A}$ \\
\hline \multirow{4}{*}{ Yeniköy } & Küçük & $881.33 \mathrm{f}$ \\
\hline & Orta & $1288.00 \mathrm{~d}$ \\
\hline & Büyük & $1821.33 \mathrm{~b}$ \\
\hline & Ortalama & $1330.22 \mathrm{C}$ \\
\hline \multirow{3}{*}{ Ortalama } & Küçük & $1078.67 c$ \\
\hline & Orta & $1521.50 \mathrm{~b}$ \\
\hline & Büyük & $2194.83 a$ \\
\hline \multicolumn{2}{|c|}{$\begin{array}{l}\text { öd: önemli değil; * }: \mathrm{P}<0.05 \\
\text { **: } \mathrm{P}<0.01 ;{ }^{* *}: \mathrm{P}<0.001\end{array}$} & $\begin{array}{l}\text { LSD }{ }_{\text {genotip: }}: 44.13^{* * *} \\
\text { LSD }_{\text {diş: }}: 24.20^{* * *} \\
\text { LSD }_{\text {genotipxdiș: }} 128.40^{* *}\end{array}$ \\
\hline
\end{tabular}


Genotip, diş büyüklüğü ve bunların interaksiyonu istatistiksel anlamda yaprak SPAD değerleri üzerine etkili bulunmuştur. Yazıköy ve Ömerce genotipleri Karnıaçık ve Yeniköy genotiplerine göre daha yoğun yeşil renkli olmuşlardır. En düşük SPAD değeri 17.88 ile Yeniköy genotipinde belirlenmiştir. Genotip diş büyüklüğü interaksiyon değerlerine göre en yüksek SPAD değeri 28 ile Ömerce genotipinin büyük dişlerinden elde edilmiştir. Oliveira ve ark. (2013), cv. 'Amarante' sarımsak çeşidinin farklı aksesyonlarında yaprak SPAD değerinin 48.83-66.97 aralığında değiștiğini belirlemişlerdir. Bu değerler bizim sonuçlarımıza göre çok yüksektir. Bitki beslenme durumu, genotip farklılığı ve bitkilerimizde gelişme devam ettiği için SPAD (yeşil renk yoğunluğu) daha düşük çıkmış olabilir.

\section{Bitki Verimi}

Yerel sarımsak genotiplerinin diș büyüklüğüne bağlı yaprak bitki verimi değerleri Çizelge 6 'da verilmiștir.

Genotip, diş büyüklüğü ve bunların interaksiyonu istatistiki olarak bitki verimi değerlerini etkilemiştir. Yazıköy genotipi $1738.55 \mathrm{~g} / \mathrm{m} 2$ bitki verimi ile en yüksek verimi vermiştir. En düşük verimli genotip Yeniköy olmuştur. Diş büyüklügüne göre büyük dişlerden gelişen bitkiler daha verimli olmuşlardır. Genotiplere göre değișmekle birlikte büyük dișler verimde \%120'ye varan oranlarda artışlar sağlamıştır.

\section{Bitki Özellikleri Arasındaki İlişkiler}

Yerel sarımsak genotiplerinin bazı bitki özellikleri arasındaki korelasyon katsayıları Çizelge 7'de verilmiştir.

Çizelge 7. Sarımsak genotiplerinde bazı bitki özellikleri arasındaki ilişkiler

\begin{tabular}{|c|c|c|c|c|c|c|c|}
\hline Bitkisel özellikler & Aks boyu & $\begin{array}{c}\text { Yeşil aksam } \\
\text { boyu }\end{array}$ & Bitki boyu & Yaprak Sayısı & Kök Uzunluğu & $\begin{array}{c}\text { Yaprak kuru } \\
\text { ağırlığl }\end{array}$ & SPAD \\
\hline Aks boyu & & 0.65 & 0.76 & 0.45 & 0.60 & 0.39 & 0.47 \\
\hline Yeşil aksam boyu & 0.65 & & 0.98 & 0.88 & 0.91 & 0.69 & 0.75 \\
\hline Bitki boyu & 0.76 & 0.98 & & 0.85 & 0.90 & 0.69 & 0.77 \\
\hline Yaprak Sayısı & 0.45 & 0.88 & 0.85 & & 0.68 & 0.91 & 0.65 \\
\hline Kök Uzunluğu & 0.60 & 0.91 & 0.90 & 0.68 & & 0.45 & 0.76 \\
\hline Yaprak kuru ağırlığı & 0.39 & 0.69 & 0.69 & 0.91 & 0.45 & & 0.60 \\
\hline SPAD & 0.47 & 0.75 & 0.77 & 0.65 & 0.76 & 0.60 & \\
\hline Bitki verimi & 0.49 & 0.86 & 0.87 & 0.90 & 0.77 & 0.81 & 0.84 \\
\hline
\end{tabular}

En yüksek korelasyon katsayısı bitki boyu ile yeşil aksam boyu ( $r=0.98^{* *}$ ) arasında belirlenmiş, bunu yeşil aksam boyu ve kök uzunluğu ( $r=0.91^{* *}$ ) ile yaprak sayısı ve yaprak kuru ağırlığı $\left(r=0.91^{* *}\right.$ ) takip etmiștir. İncelenen bitki özelliklerinde bitki boyu diğer tüm özelliklerle arasında olumlu ve önemli $r=0.69-0.98$ oranında ilişkiler belirlenmiştir. Benzer şekilde yeşil aksam boyu ile de diğer tüm özelliklerle arasında olumlu ve önemli $r=0.65-0.98$ oranında ilişkiler Aks boyu ile yeşil aksam boyu, bitki boyu ve kök uzunluğu arasında olumlu ve önemli ilişkiler tespit edilmiştir. Kök uzunluğu ile bitki boyu ve yeşil aksam boyu arasında yüksek bir ilişkinin belirlenmiş olması bitki gelişim fizyolojisi ile yakından ilişkilidir. Singh ve ark. (2011) bitki boyu ile total hasat verimi arasında olumlu ve önemli bir ilişkinin $\left(\mathrm{r}=0.652^{* *}\right)$ varlığını iafade etmişlerdir. de Andrade Júnior ve ark. (2019) sarımsakta bitki boyu ile yumru verimi arasinda olumlu ve önemli bir ilişkinin $\left(\mathrm{r}=0.65^{* *}\right)$ olduğunu belirtmişlerdir. Diğer yandan bizim bulgularımızın aksine araştırıcılar bitki boyu ile yaprak sayısı arasında zıt bir ilişki ( $\mathrm{r}=-$ $0.51^{*}$ ) tespit etmişlerdir.

\section{Sonuç}

Taşköprü sarımsak genotiplerinin farklı diş büyüklüklerinde taze sarımsak performansları arasında incelenen parametreler yönünden önemli değişimler gözlenmiştir. Bitki verim değerleri açısından Yazıköy genotipi en yüksek verimi vermiştir. Karnıaçık genotipi verim açısından ikinci sırada yer almıştır. Çalışmada salt morfolojik özellikler üzerinden bir değerlendirme yapılmıș olup, herhangi bir duyusal analiz yapılmamıștır. Duyusal test yapılarak farkl genotiplerin taze sarımsak kaliteleri belirlenerek taze tüketime uygunları değerlendirilebilir. Diş büyüklüğü incelenen tüm bitkisel özellikler açısından önemli değişimlere neden olmuş, büyük dişler en yüksek değerleri vermiştir. Baş sarımsak tarımında büyük ve orta büyüklükteki dişlerin kullanılması, küçük dişlerin taze üretimde değerlendirilmesi şeklinde bir uygulama homojen üretim ve kalite açısından önemli görülmektedir. Taze sarımsak üretiminde küçük dişlerde daha sık dikimler ve özellikle azotlu gübre uygulamaları ile verimler üst seviyelere taşınabilir. Dişlerin geç sonbaharda dikimi ve erken baharda 
taze sarımsak üretimi ile kalite yönünden avantaj sağlayabilir. Üretim sürekliliği ve verimlilik açısından su kültürü denemelerine yer verilmesi farklı sonuçlara ulaşmamıza imkan verebilir.

\section{Çıkar çatışması}

Yazarlar arasında herhangi bir çıkar çatışması yoktur.

\section{Yazarların katkı beyanı}

AU: Konsept ve dizayn, Veri toplama, Veri analizi ve yorumlama, Makalenin yazılması, Makalenin içeriğinin gözden geçirilmesi, İstatistiksel analiz; ÖI: Veri toplama, Veri analizi ve yorumlama, Makalenin yazılması; UU: Veri toplama, Veri analizi ve yorumlama, Makalenin yazılması.

\section{Kaynaklar}

Agarwal, K. C. (1996). Therapeutic actions of garlic constituents. Medicinal Research Reviews, 16(1), 111-124.

Akan, S. (2019). Evaluation and comparison of some parameters in four garlic varieties. Iğdır Üniversitesi Fen Bilimleri Enstitüsü Dergisi, 9(4), 1866-1875.

Akan, S., Horzum, Ö., \& Güneş, N. T. (2019). Modifiye atmosferli paketlemenin yeşil sarımsak (Allium sativum L.) yapraklarında kalite korunumuna etkisi. Mustafa Kemal Üniversitesi Tarım Bilimleri Dergisi, 24(3), 165-173.

Anonim (2021). Sarımsak Ocak 2021,Tarım Ürünleri Piyasa Raporu, Tarım Orman Bakanlığı, Tarımsal Ekonomi ve Politika Geliștirme Enstitüsü, Ankara. Web: https://arastirma.tarimorman.gov.tr/tepge /Belgeler/PDF...pdf (Erişim tarihi: 13.04.2021).

Arzanlou, M., \& Bohlooli, S. (2010). Introducing of green garlic plant as a new source of allicin. Food chemistry, 120(1), 179-183.

Ayaz, E. \& Alpsoy, H. C. (2007). Sarımsak (Allium sativum) ve geleneksel tedavide kullanımı. Türkiye Parazitoloji Dergisi, 31, 145-149.

Bakır, A. (1996). Sarımsak (Allium sativum L.)'ta Farklı Dikim Zamanlarının Verim ve Kaliteye Etkisi. Yüksek Lisans Tezi, Ege Üniversitesi Fen Bilimleri Enstitüsü, İzmir, 65 s.

Batcioglu, K., Yilmaz, Z., Satilmis, B., Uyumlu, A. B., Erkal, H. S., Yucel, N., Gunal, S., Serin, M., \& Demirtas, H. (2012). Investigation of in vivo radioprotective and in vitro antioxidant and antimicrobial activity of garlic (Allium sativum). European Review for Medical and Pharmacological Sciences, 16, 47-57.

de Andrade Júnior, V. C., Guimarães, A. G., Firme, T. D., Costa, A. A. A., Costa, M. R. D., Lopes, T. K., de Souza,
R. J., \& Resende, F. V. (2019). Associations between morphological and agronomic characteristics in garlic crop. Horticultura Brasileira, 37(2), 204-209.

Dehkordi, S. H., Moghadam, A. Z., Maghsoudi, N., Aali, E., Gerami, R., \& Dehsadeghi, E. (2010). The effects of fresh garlic on the serum concentration of total cholesterol, total triglyceride and adipose tissues of broilers. Comparative clinical pathology, 19(4), 363365.

Gadel-Hak, S. N. H., Moustafa, Y. M. M., Abdel-Naem, G. F., \& Abdel-Wahab, I. A. (2011). Studying different quantitative and qualitative traits of some whiteand colored-bulb garlic genotypes grown under a drip irrigation system. Australian Journal of Basic and Applied Sciences, 5(6), 1415-1427.

Gaiki, U. R., Jogdande, N. D., Dalal, S. R., Nandre, D. R., \& Ghawade, S. M. (2006). Effect of biofertilizers under reduced doses of inorganic fertilizers on growth and yield of garlic. Plant Archives, 6(1), 367-368.

Geboloğlu, N., Karabekiroğlu, D. S., \& Doksöz, S. (2017). Tokat sarımsağının morfolojik ve moleküler karekterizasyonu. Akademik Ziraat Dergisi, 6, 131136.

Güral, M. Ö. (2014). Bazı Yerel Soğan (Allium cepa L.) Genotiplerinin Yeşil Soğan Üretimindeki Performanslarının Belirlenmesi. Yüksek Lisans Tezi, Ordu Üniversitesi Fen Bilimleri Enstitüsü, Ordu, $60 \mathrm{~s}$

Hall, A., Troupin, A., Londono-Renteria, B., \& Colpitts, T. M. (2017). Garlic organosulfur compounds reduce inflammation and oxidative stress during dengue virus infection. Viruses, 9(7), 159.

Kik C, Kahane R, Gebhardt R. (2001). Garlic and health. Nutr Metab Cardiovasc Dis, Aug;11(4 Suppl):57-65.

Kütevin, Z., Türkeş, T. (1987). Sebzecilik ve Genel Sebze Tarımı Prensipleri ve Pratik Sebzecilik Yöntemleri. İnkilap Kitabevi, Ankara cad: 95, İstanbul

Oliveira, N. L. C. D., Puiatti, M., Finger, F. L., Fontes, P. C. R., Cecon, P. R., \& Moreira, R. A. (2018). Growth and yield of'Amarante'garlic accessions. Revista Ceres, 65(6), 481-490.

Peker, S. (2019). Diyarbakır koșullarında sarımsak yetiştiriciliğinde farklı dikim tarihlerinin hasat, verim ve kalite üzerine etkisi. Yüksek Lisans Tezi, Dicle Üniversitesi Fen Bilimleri Enstitüsü, Ordu, 70s.

Raman, P., DeWitt, D. L., \& Nair, M. G. (2008). Lipid peroxidation and cyclooxygenase enzyme inhibitory activities of acidic aqueous extracts of some dietary supplements. Phytotherapy Research: An International Journal Devoted to 
Pharmacological and Toxicological Evaluation of Natural Product Derivatives, 22(2), 204-212.

Santhosha, S. G., Jamuna, P., \& Prabhavathi, S. N. (2013). Bioactive components of garlic and their physiological role in health maintenance: A review. Food Bioscience, 3, 59-74.

Singh, R. K., Dubey, B. K., Bhonde, S. R., \& Gupta, R. P. (2011). Correlation and path coefficient studies in garlic (Allium sativum L.). Journal of Spices and Aromatic crops, 20(2), 81-85.

Tapiero, H., Townsend, D. M., \& Tew, K. D. (2004). Organosulfur compounds from alliaceae in the prevention of human pathologies. Biomedicine \& Pharmacotherapy, 58(3), 183-193.
Torres-Palazzolo, C. A., Ramírez, D. A., Beretta, V. H., \& Camargo, A. B. (2021). Matrix effect on phytochemical bioaccessibility. The case of organosulfur compounds in garlic preparations. LWT, 136, 110301.

Vural, H., Eşiyok, D., \& Duman, İ. (2000). Kültür Sebzeleri (Sebze Yeyiştirme). Ege Üniversitesi Basımevi, Bornova/İZMIR. $440 \mathrm{~s}$.

Zambi, O. (2015). Arpacık İriliği ve Bor Uygulamalarının Yeşil Soğanda (Allium cepa L.) Verim ve Kaliteye Etkisi. Yüksek Lisans Tezi, Ordu Üniversitesi Fen Bilimleri Enstitüsü, Ordu, 66 s. 